\title{
Teachers and Students Views on the use of IWBs in Secondary Schools for Enhancing Classroom Teaching and Learning
}

\author{
Omer CAKIROGLU ${ }^{1}$ \\ ${ }^{1}$ Prof. Dr. Istanbul University, Hasan Ali Yücel Faculty of Education,ocakin@istanbul.edu.tr
}

\begin{abstract}
This study was on teachers and students' views on the use of Interactive Whiteboards (IWBs) for enhancing classroom teaching and learning in the secondary schools' teachers and students in $6^{\text {th }}$ grades. The study includes 392 sixth grade students in 14 primary schools and 142 teachers (sciences, mathematics and English) teaching sixth grades in 18 primary schools from different classes in the city of Istanbul. Quantitative research method design was conducted as well as survey method. The questionnaire administered to teachers and students involved 19 closed questions (Yes/No) and 23 Likert-type questionnaire were used to collect data on the IWB use for classrooms teaching and learning. Mean score of 19 closed items were 73.65. Of 23 items, mean scores of 3,6 items were higher than 3.00 and only two items were lower than 3.00. Reliability for Likert-type items is excellent (0.91). The results of the study show that IWB use contributes to teaching and learning.
\end{abstract}

Keywords: Interactive whiteboards; improving teaching and learning; grade sixth; Quantitative research method

\section{Ortaokullarda Akıllı Tahta Kullanımının Öğretim ve Öğrenimi Geliştirmede}

\section{Öğretmen ve Öğrenci Görüşleri}

\section{ÖZ}

Bu çalışma, ortaokul 6. sınıflarda öğretimi ve öğrenimi iyileştirmek için akıllı tahta (IWBs) kullanımı hakkında öğretmen ve öğrenci görüşleri üzerinedir. Çalışmaya, 6. sınıflarda 18 ortaokulda (142) fen, matematik ve Ingilizce öğretmeni ve 14 ortaokulda (392) altıncı sınıf öğrencisinin katılımı ile Istanbul'da farklı okullarda yapılmıştır. Çalışmada, nitel araştırma metodu kullanılmıştır. Araştırmadaki soruların 19 tanesi kapalı (Evet / Hayır) ve 23 tanesi Likert-tipidir. Elde edilen skorlar göstermiştir ki; 11 sorunun ortalaması ellinin 73.65 üzerindedir. Sadece 2 sorunun ortalaması 3’ün altındadır. Likert-tipi soruların güvenirlik katsayıları mükemmel $(\alpha=0.91)$ olarak bulunmuştur. Sonuçlar göstermiştir ki, IWB kullanımı öğretim ve öğrenime katkı sağlamaktadır.

Anahtar Kelimeler: Akıllı Tahta; öğretim ve öğrenimin iyileştirilmesi; altıncı sınıf; nicel araştırma yöntemi 


\section{INTRODUCTION}

Recently, educational technology tools have been widely used in classrooms, one of which is the Interactive Whiteboard (IWB) (Betcher \& Lee, 2009; Pour, 2013). Educational technology equipment, IWB, has developed in parallel with the increased importance of technology in education. With the increase in the importance of education, the use of technology products in education has been increased in parallel. This modern device, an electronic Interactive White Board (IWB), is known under different brands such as Smartboard and Promethean, has replaced traditional black boards in most schools development-developing countries (Becta, 2006) for supporting enhancing teaching and learning (Kristian \& Lynn, 2011; Turel \& Johnson, 2012; Yang \& Teng, 2014; Ghavifekr \& Rosdy, 2015; Kayak \& Kır, 2015). This equipment has been manufactured by Smart Technology since 1991 (Smart Technology, 2006), and it has been used in education since 1997 (Cogil, 2002). In Turkey, Istanbul Technical University began using it in 2003 (Private Communication), and since then it has been extensively in the Turkish primary and secondary classrooms as well as in other countries (European Commission Report, 2013; Akkoyunlu \& Baskan, 2015; Balta \& Duran, 2015). There is no doubt that the IWB technology is an excellent contemporary tool in education (Georgieva, Stoykova, Ivanova \& Dimova 2015; Kilic, Guler \& Tatli, 2015) and today, it has become a popular educational equipment in classrooms (Becta, 2008; Littleton, 2010). According to the ECR (2013) and Karsenti (2016) , IWB use in classrooms varies according to countries (Figure 1) and (Figure 2), respectively. Some countries such as UK, USA, Canada, Taiwan, Japan, Malaysia China and Australia have invested enormous amounts of money on IWBs (Karsenti, 2016) and they are also aware of the importance of using this technology, and they are also willing to integrate IWBs in teaching and learning (Emron \& Dhindsa, 2010; Ghavifekr \& Rosdy, 2015). In these two references, IWB has a high prevalence in primary $(100 \%)$ and secondary schools $(98 \%)$ in UK and they are compatible on England and most countries. Globally, IWB use is becoming increasingly popular, at all levels but especially in the lower grades, so is Turkey too. This context, in early 2013, the Turkish government has approved an open bid system for the purchase of 13 million tablet PCs under the Fatih Project by 2016, as many as 16 million tablets will be distributed in primary schools in order to improve educational technology conditions and increase the efficiency of the learning in primary and secondary schools as part of this project (Kurt, 2013; Akkoyunlu \& Baskin, 2015; Dogan, Cinar \& Seferoglu, 2016). According to ECR (2013), Turkey will soon rank second globally in the use of tablet PCs in primary schools. For most of the world, IWB is one of the most current modern educational technology tools and according to predictions based on research, use of its in classrooms will continue to expand as seen in Figure 1 (Karsenti, 2016). As seen in Figure 1 and Figure 2, evaluation of ECR (2013) and Karsenti (2016) report are incompatible with Turkey.

As soon as IWB was introduced in the classrooms, it has noticeably contributed to the effectiveness of teaching and learning process, which has been a reform in classrooms (Digregorio \& Sobel-Lojeski, 2010; Yang \& Teng, 2014). The current works suggests that when IWBs are implemented to provide some benefits to teachers and students in teaching and learning process. 
The current study focuses on the investigation of the contribution of IWB use in teaching and learning, according to teachers' and students' views in the elementary schools. In particular, research focuses on the quality of teaching and learning using IWBs Therefore, the contribution of this technological tool in teaching and learning was investigated from both the student and teachers' views.

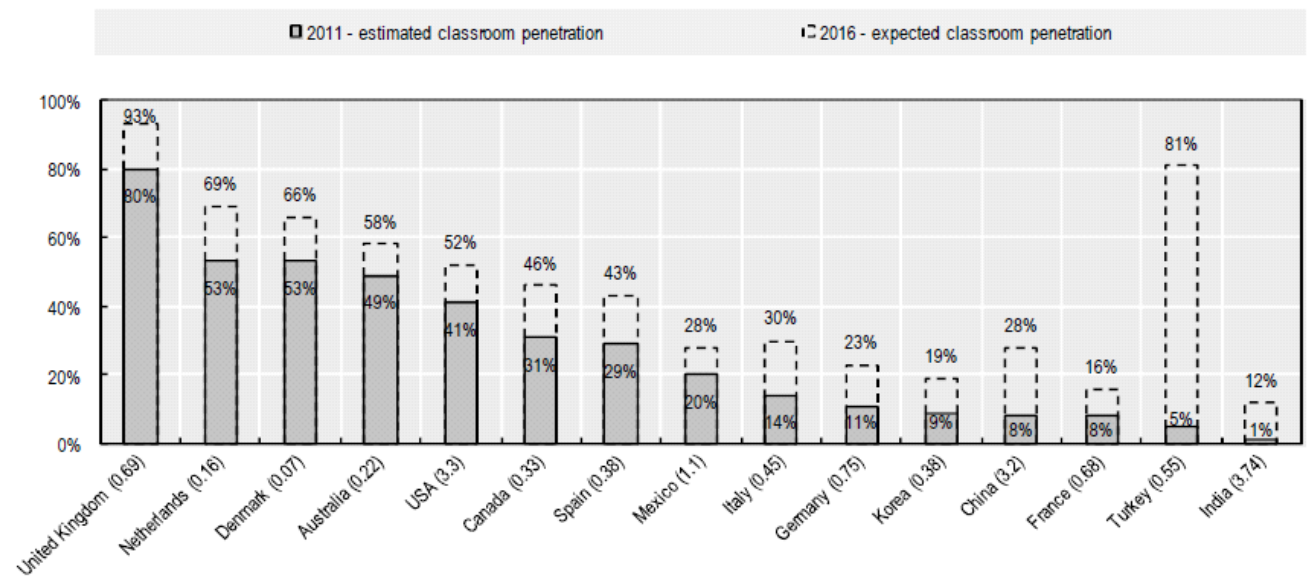

Figure 1. Classroom penetration of IWBs globally. The total number of classrooms (teaching spaces) in each country is given in parentheses (European Commission Report, 2013).

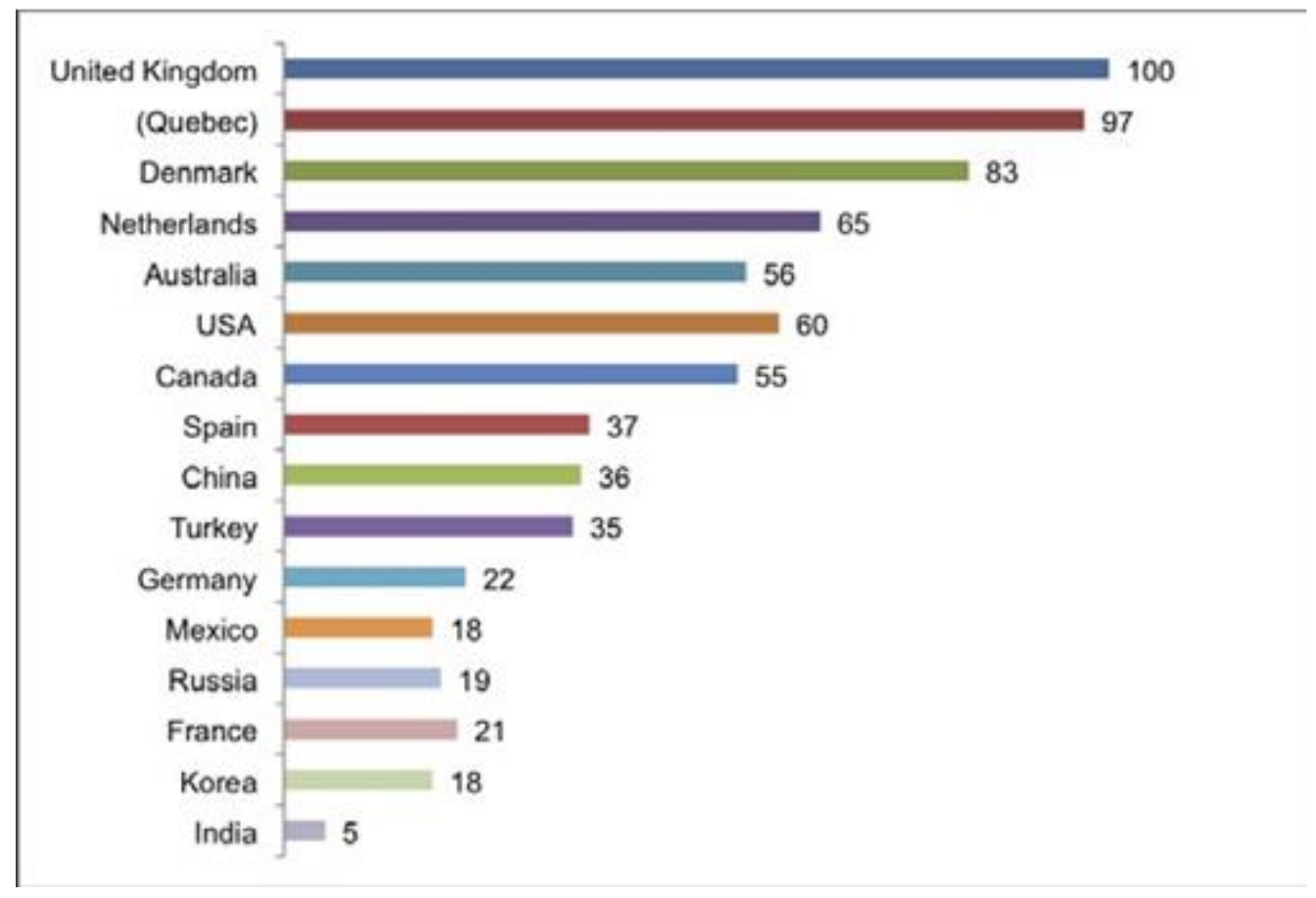

Figure 2. Presence of interactive white boards (IWB) in classrooms of various countries (Karsenti, 2016)

\subsection{Literature review on advantages of using IWB in the classroom}

Courses based on IWB in the classroom provide some important benefits and conveniences to the education process. With IBW technology, subjects are processed both visually and verbally, teaching and 
learning become easier and knowledge transfer becomes more permanent (Beeland, 2003; Hennesy \& Warwick, 2010). Since the teachers must prepare the necessary course materials beforehand and they can focus directly on the topic of the lesson (Hall, 2011). Meanwhile, the teacher can determine students' requirements, what they learn in detail and how much they understand (Liang, 2012). IWB is able to engage the entire class thereby gaining the students' interest - enhancing engagement Jankawaska \& Atalay, 2008; Morgan, 2008) and increasing their self-confidence (Hartsel, Herron, Fang \& Radhod, 2010). Teacher creates a variety of different teaching styles into the lesson (Mavers, 2009). IWB provides opportunities such as ease in reviewing previous subjects of students, doing repetition work (Digregorio \& Sobel-Lojeski, 2010), easy access to knowledge- resources and the output of the texts for sharing by Internet (Khan, Mayers, Gowen \& Bergman, 2014). These can also reuse in the future (Interactive Technology, 2010) and it saves time (Beauchamp \& Parkinson 2005; Tertemiz, Sahin, Can \& Duzgun, 2015). Additionally, IWB plays an important role for applying the question-answer education method and immediate feedback (Xu \& Moloney, 2011). Due to IWB storage capabilities, thousands of animations, questions, maps, pictures, films and documents are available for reuse, teachers represent the topics in a better and easier way (Glover, Miller, Averis \& Dooret, 2005; Karsenti, 2016). IWB increases student attendance (Wood \& Ashfield, 2008), motivates students to try harder, makes them more competitive (Interactive Technology, 2010), and encourages collaboration among students (Armstrong et al., 2005). It raises their level of interest and motivation (Ardichvili, 2008; Cintia, Gheorghiu \& Colibaba, 2014), maintains their attention for a longer period of time and improved energy levels and encourages active participants (Digregorio \& Sobel-Lojeski, 2010; Tirotta, Torff \& Tirotta, 2010). IWB contributes to more articulate presentations and enhances social skills of students (Mercer, Warwick, Keshner \& Staarman, 2010). Students tend to learn more easily by visual and auditory modalities (Rule, Stefanich, Boody \& Peiffer, 2011). Furthermore, the class is fun and is not stressful for the students (A1-Shenton \& Padgett, 2007). These factors show that the IWB makes teaching and learning easier and quicker.

\subsection{Purpose of the study}

The study aims to evaluate and to analyze how secondary school $6^{\text {th }}$ grade teachers and students view on the contribution of the use of IWB technology to teach and learn. Within the main purpose of this context the research lines of this study are listed as follows;

- Reasons for selecting the grade $6^{\text {th}}$;

-Teachers and students view on IWB use;

-Teachers' and' students view on IWB use as contribution of teaching and learning;

\section{METHODOLOGY}

The design for this research study is a quantitative research method (Sofaer, 2002)

\subsection{Participants}

One hundred and forty two different 6th grade teachers from 18 different secondary schools and 392 sixth grade students from fourteen different elementary schools have participated in this study in Istanbul, 
Turkey. Number of public and private schools are equal. As much as possible, schools were selected that had good quality IWBs and teachers who were actively using them and all of them were teaching science, mathematic and English. Pre-studies were performed at other schools, which had the same specifications. According to the results of pre-studies, it was concluded that the grade 6 is the most appropriate level (Cakiroglu, 2015). Fifty-seven and seventy-five percent of the teachers and $60.71 \%$ of the students are in public schools. The majority of teachers $(79.18 \%)$ are female and their experiences varied from 1 to 33 years.

\subsection{Data collection}

In this study, data were collected by quantitative. Data were collected during the spring education semester of the school year 2015-2016. Quantitative data were collected by the survey questions. To measure views on the impact of teaching and learning using IWB. To measure teachers and students view on IWB use (11closed and 12 Likert types) and as contribution of teaching and learning IWB use (13) questions were implemented. Since teacher participation was also voluntary and there was no time limit for teachers. Surveys were performed to students during a four-week period, on different days with equal time intervals. The questionnaires were answered by teachers and students and then evaluated.

\subsection{Instrument development}

The goal of current research was to determine the views of teachers and students towards teaching and learning on use of IWB. The survey scale created for research were distributed for feedback from 6 teachers and 7 students at 4 different schools. Teachers who were determined to according to voluntary basis and they were selected by their field of expertise for critics on questionnaires. The questionnaire on the development of scale, it is formed from the intriguing questions and to ensure the reliability of the research, the survey questions were arranged so that the consistency of the answers of the teachers and the students could tested. Some questions and answers of participants were denoted "/", e.g:teacher(s) / student(s), teaching / learning. To increase validity of the survey questions, three experienced teachers from different secondary schools carefully reviewed all items of the instruments and vague items, words and unnecessary items were excluded or reduced according to experts' opinions. After review by three experts in survey questions, they were administered to the participants. For responses in the multiple choice section, the 5-point Likert scale was used (1: Strongly Disagree, 2: Disagree, 3: No idea, 4: Agree, 5: Strongly Agree). The overall Cronbach's Alpha coefficients for survey multiple choice questions estimated for the instruments were computed by using SPSS and the limits of validity of its coefficients for internal consistency are evaluated (Streiner, 2003).

\subsection{Data analysis}

The collected data were analysed using SPSS 21 packet programme version 21. The scores in the Likert scale are between 1 and 5 . If the score approaches 5 , the positive rate is high. The analysis issues in the text can be classified according to the Likert scale: agree (A=agree+strongly agree) and disagree $(\mathrm{DA}=$ disagree + strongly disagree). Arithmetic Mean for each question (M), standard deviations (SD) and percentage of frequency were calculated using - the same program and were given in tables in the text. For the reliability and internal consistency of the values in the tables, Cronbach's alpha coefficients are calculated and interpreted by the limits of validity. 


\section{FINGINGS}

The results of the views of the teachers and the students about the IWB use in classrooms were analysed together. According to the results of pre-studies, it was concluded that the grade 6 is the most appropriate level because the rank of their response are the highest. Another reason for the selection of the sixth grade, children at this age is generally passed from abstract thinking to concrete thinking (Cakiroglu, 2015). Teachers were selected from sixth grade teachers, who use the most often the IWBs.

\subsection{Teachers and students view on IWB use}

Nineteen closed questions were asked in order to determine the general view of teachers and students about IWB use in classrooms. The results of teachers and students are presented in same table (Table 1).

Table 1. Descriptive statistics of teacher and students `views toward IWBs use

\begin{tabular}{|c|c|c|c|c|}
\hline & $\begin{array}{l}\text { Teacher: } N=142 \text {, Students: } 392 \text {. Percentages of teachers / students' } \\
\text { evaluate statement about IWB }\end{array}$ & $\begin{array}{l}\text { Positive } \\
\text { (Yes) }\end{array}$ & Neutral & $\begin{array}{l}\text { Negative } \\
\text { (No) }\end{array}$ \\
\hline 1 & Are you satisfied with the IWB usage in the classroom & $77 / 83$ & $1 / 3$ & $22 / 14$ \\
\hline 2 & Are there advantages of using the IWB in classrooms? & $79 / 82$ & $6 / 5$ & $15 / 13$ \\
\hline 3 & Does IWBs help the lesson be more interactive & $86 / 84$ & $1 / 2$ & $13 / 14$ \\
\hline 4 & $\begin{array}{l}\text { Do you think some teaching and learning made easier through IWB } \\
\text { use? }\end{array}$ & $74 / 81$ & $3 / 2$ & $23 / 17$ \\
\hline 5 & Do students focus on lesson more when IWB use in classroom? & $85 / 82$ & $2 / 4$ & $13 / 14$ \\
\hline 6 & $\begin{array}{l}\text { Does IWB increases collaboration and communication among } \\
\text { students? }\end{array}$ & $87 / 79$ & $0 / 3$ & $13 / 18$ \\
\hline 7 & $\begin{array}{l}\text { Do you have a preferred teaching / learning style such as whole } \\
\text { class group? }\end{array}$ & $67 / 72$ & $1 / 7$ & $28 / 21$ \\
\hline 8 & Do you study hard, if IWB is used more often in classroom? & $-/ 69$ & $-/ 5$ & $-/ 26$ \\
\hline 9 & Do you think that homework is better reviewed using IWB? & $68 / 73$ & $9 / 8$ & $23 / 19$ \\
\hline 10 & $\begin{array}{l}\text { Do you understand subjects better when teaching / learning is done } \\
\text { with IWB compared to ordinary learning courses? }\end{array}$ & $77 / 79$ & $4 / 5$ & $19 / 14$ \\
\hline 11 & $\begin{array}{l}\text { Do you think that classical explanation of subjects is better with } \\
\text { IWB use compared to explanations with WB }\end{array}$ & $67 / 64$ & $9 / 11$ & $24 / 23$ \\
\hline 12 & $\begin{array}{l}\text { Do you think that the handouts are a good help in the IWB courses } \\
\text { to teaching / learning better? }\end{array}$ & $61 / 63$ & $15 / 12$ & $24 / 25$ \\
\hline 13 & $\begin{array}{l}\text { Do you teach / learn better with using IWB the topics content the } \\
\text { image, auditory, digital and figure? }\end{array}$ & $80 / 84$ & $3 / 2$ & $17 / 14$ \\
\hline 14 & $\begin{array}{l}\text { Does the use of IWB in the classrooms benefit of presentation your } \\
\text { works? }\end{array}$ & $59 / 57$ & $11 / 14$ & $30 / 29$ \\
\hline 15 & $\begin{array}{l}\text { Does IWB' use in classroom increase students' academic } \\
\text { performance }\end{array}$ & $84 / 87$ & $2 / 7$ & $11 / 6$ \\
\hline 16 & What are the views towards using IWB in classrooms? & $62 / 65$ & $11 / 12$ & $27 / 23$ \\
\hline 17 & Will you advice your classmates the use IWB in their classrooms? & $77 / 83$ & $1 / 2$ & $22 / 15$ \\
\hline 18 & Will you use IWB in future? & $85 / 88$ & $0 / 1$ & $15 / 11$ \\
\hline 19 & Which one do you prefer in class: IWB (Yes) WB (No)? & $79 / 84$ & $2 / 0$ & $16 / 1$ \\
\hline
\end{tabular}

Majority of participants indicated mostly positive views towards IWBs. Positive responds of the participants were $\% 75.05$ for the teachers and $\% 76.63$ for the students.

\subsection{Teachers' and students' view on IWB use as contribution of learning}

The quintet-point Likert-type 23 questions were asked to teachers and students in order to examine the teachers' and students' view on IWB use the contribution of teaching and learning in different perspective. The response of the vast majority of participants are almost positive views towards the use of IWB technologies' contribution to teaching and learning in 6th grade classrooms. Mean of the teachers 
and students were almost 3.51 and 3.58, respectively. The reliability coefficient for this part of the instrument is 0.91 (Table 2 ).

Table 2. Teachers' and students' views on the impact of contribution of learning of the IWB use $\alpha=.91$, Teacher: $\mathrm{N}=142$, Students:392. Percentages of teachers / students Disagree(DA)/Agree (A) with each statement

\begin{tabular}{|c|c|c|c|c|c|}
\hline & Statements & Mean & SD & $\mathrm{DA}$ & A \\
\hline & \multicolumn{5}{|l|}{ IWB contributes ............................. } \\
\hline 1 & $\begin{array}{l}\text { for a higher proportion of motivation, energy and } \\
\text { eagerness }\end{array}$ & $3,88 / 3,89$ & $1,14 / 1,13$ & $19,8 / 17,9$ & $76,8 / 74,6$ \\
\hline 2 & to make lessons more interesting & $4,17 / 4,18$ & $0,89 / 0,88$ & $9,4 / 8,9$ & $80,2 / 82,5$ \\
\hline 3 & to make the subject easier and understandable & $3,08 / 3,06$ & $1,37 / 1,39$ & $10,8 / 56,8$ & $62,3 / 57,4$ \\
\hline 4 & $\begin{array}{l}\text { to the competitiveness and argumentativeness of the } \\
\text { class }\end{array}$ & $3,34 / 3,69$ & $1,30 / 1,28$ & $15,2 / 17,6$ & $66,9 / 67,5$ \\
\hline 5 & to the creativity of the class & $3,69 / 3,68$ & $1,28 / 1,29$ & $18,7 / 19,4$ & $69,0 / 68,4$ \\
\hline 6 & to the concentration on the subject & $3,74 / 3,44$ & $1,25 / 1,23$ & $15,8 / 14,1$ & $59,8 / 61,9$ \\
\hline 7 & to the activeness of the classrooms & $3,11 / 4,09$ & $1,02 / 0,98$ & $14,1 / 10,2$ & $72,3 / 75,6$ \\
\hline 8 & to make lessons more fun and enjoyable & $4,12 / 4,14$ & $0,68 / 0,67$ & $6,1 / 3,6$ & $89,2 / 91,4$ \\
\hline 9 & to the plan and organisation of the lesson & $2,712,72$ & $1,46 / 1,40$ & $25,6 / 24,4$ & $69,1 / 71,4$ \\
\hline 10 & to the instant feedback between student and teacher & $3,48 / 3,67$ & $1,20 / 1,19$ & $18,6 / 18,4$ & $68,2 / 67,9$ \\
\hline 11 & to teaching / learning easier and without stress & $3,41 / 3,43$ & $1,33 / 1,31$ & $15,8 / 12,6$ & $66,2 / 67,8$ \\
\hline 12 & to reviewing past subjects easily & $3,71 / 3,72$ & $1,19 / 1,19$ & $15,5 / 14,9$ & $54,6 / 55,2$ \\
\hline 14 & for many new opportunities in teaching / learning & $3,98 / 3,39$ & $1,09 / 1,07$ & $16,3 / 15,8$ & $66,4 / 69,2$ \\
\hline 15 & to practice more in the lessons & $3,93 / 3,95$ & $1,02 / 1,01$ & $13,4 / 10,8$ & $71,4 / 78,1$ \\
\hline 16 & to applying many virtual experiments & $3,94 / 3,93$ & $1,02 / 1,02$ & $15,4 / 16,8$ & $72,5 / 71,8$ \\
\hline 17 & in increased my curiosity towards the use of technology & $3,71 / 3,71$ & $1,19 / 1,18$ & $17,4 / 18,7$ & $69,7 / 70,3$ \\
\hline 18 & to presenting and exploring & $4,01 / 4,07$ & $0,78 / 0,77$ & $10,8 / 9,7$ & $84,4 / 86,7$ \\
\hline 19 & $\begin{array}{l}\text { to provide easy display for visual documentation, such } \\
\text { as pictures, diagrams, videos and animations }\end{array}$ & $4,18 / 4,22$ & $0,71 / 0,69$ & $7,4 / 5,8$ & $91,4 / 93,3$ \\
\hline 20 & to teaching / learning topics in greater depth & $3,87 / 3,90$ & $1,09 / 1,08$ & $16,1 / 18,7$ & $65,3 / 66,2$ \\
\hline 21 & to fulfilling the teaching and learning goals & $3,71 / 3,70$ & $1,24 / 1,25$ & $15,8 / 16,2$ & $67,4 / 66,3$ \\
\hline 22 & collaboration and communication among students & $3,69 / 3,72$ & $1,27 / 1,25$ & $18,1 / 17,8$ & $68,4 / 66,4$ \\
\hline 23 & to increases students' academic performance & $4,16 / 4,18$ & $0,71 / 0,70$ & $7,4 / 6,9$ & $87,4 / 90,3$ \\
\hline
\end{tabular}

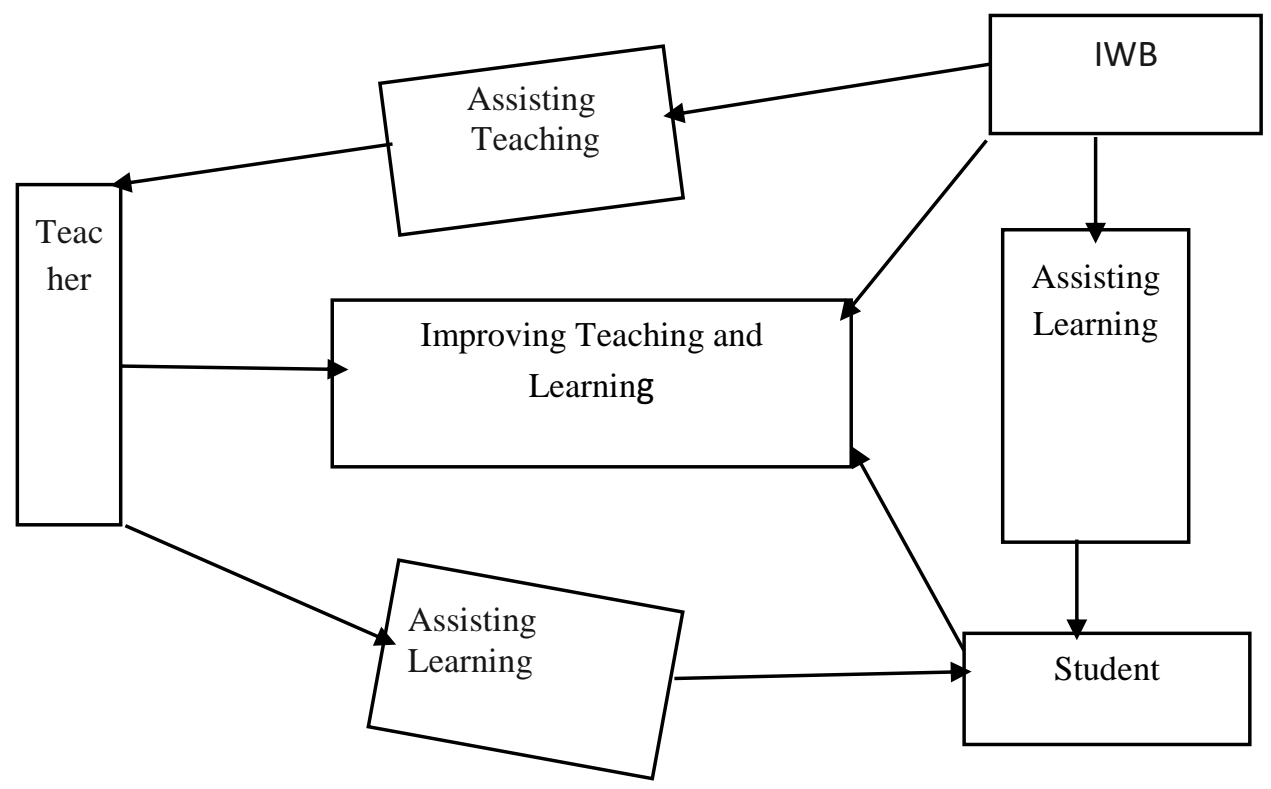

Figure 3. Teaching and learning relation among the teacher-student-IWB cycle are clearly emerged 


\section{DISCUSSIONS}

As in other countries of the world, the use of IWB in the classroom is increasing rapidly in Turkey. It is predicted that by 2016, through Fatih project, Turkey is expected to have the second highest use of IWB (Figure 1), just behind the United Kingdom (Kurt, 2013; European Commission Report, 2013). Somehow, according to Karsenti report (2016), IWB use in various schools in Turkey is thirty-five percent (Figure 2).

Among those sixth grade teachers, the IWB have been more frequently used by science, mathematics and English teachers, which was identified in our previous research. As the ages and grade levels of the students' increase, interest in and positive views towards IWB decrease and children at the grade $6^{\text {th }}$ age is generally passed from abstract thinking to concrete thinking (Cakiroglu, 2015).

Views of teachers and students on IWB use in classrooms were investigated in various aspects. Participants general views towards the use of IWB are strongly positive (Yes) (Table 1). The mean percentage of this section is $75.05 \%$ and $76.63 \%$ for teachers and students, respectively. The six score are quite high. Especially question 6, which have high score. Two of them Q3(86/84) is that IWB helps the lesson to be more interactive and students focus on lesson more Q5(85/82). The responds of teachers and students for Q6 (86/79), IWB increases collaboration and communication among students, is exhibited difference as seen in Ref. (Armstrong, Barnes, Sutherland, Curran, Mills \& Thompson, 2005). In this questions, the score of students is slightly lower than teacher. Because, in most of results, students' responds are higher than teachers. In particular, the image, auditory, digital and figure content Q13(80/84) has quite high score. It is understood from this finding that visual and experiential activities using IWBs have great impact on teaching and learning. The results of Q15 (84/87) is important for our research because of increasing students' academic performance. Similar findings are found in the literature (Lopez, 2010; Digregorio \& Sobel-Lojeski, 2010; Swan \& van't Hooft, 2012). It is understood from this result, the IWB contributes to teaching and learning, which is the most important findings for our study. Because it constitutes the base of the aim of our study. In the same Table 1 the Q18 (85/88); it includes the teaches and students will use IWB in classrooms in future, which is the most important for using technology in classrooms. According to the participants are strongly identified the use of IWB in classrooms in the future. This findings confirm the previous studies (Celik, 2012; Tomei, 2013; Balta \& Duran, 2015; Tertemiz, Sahin, Can \& Duzgun, 2015).

In the second section Table 2, the contributonal effect of IWB use of participants' view is investigated. The mean score of teachers' and students' view on the contribution of the use of IWB to teaching and learning is 3.54 and 3.58, respectively. Their views on IWB use as contribution of teaching and learning are strongly positive for questions 1 to $23(\alpha=0.91)$. In Table 2, some scores are quite high: Especially Q2 (4.17/4.18), Q8 (4.12/4.14), Q19 (4.18/4.22) and Q23(4.17/ 4.18). According to the response of the participants, IWB makes the courses interesting (Q2) and makes lessons more fun and enjoyable (Q8). These two results show that thanks to the IWB the students listen the lesson and keep their attention during the courses. The interest of teachers towards the use of IWBs and other educational technology tools are extremely high (Q13) (Mathews-Aydinli \& Elaziz, 2010; Balta \& Duran, 2015). In particular, the visual and experiential content Q19 has the highest score. It is understood from this finding 
that visual and experiential activities using IWBs have the highest impact on teaching and learning. The IWB that make up the theme of our study is related to the contribution of teaching and learning in the view of participants. When they are asked whether the use of IWB contributed with their teaching and learning, the responses of them are strongly positive and the IWB contributes to increases students' academic performance Q23. This finding is an important for in the future study. Similar findings on the contributions of IWBs to academics were found in previous research (Lopez, 2010; Manny-Ikan, Dagan \& Mada, 2011; Tunaboylu \& Demir, 2016). In the cycle of teacher, student and IW; this combination has an important role for relationship in teaching and learning (Figure 1). From this schema, how these trios are intertwined in teaching and learning, and IWB technology emerges the contribution to teaching and learning.

It is clear that responses of teachers and students in two section are closed and overlapped but somehow students' responses slightly higher than teachers. In our opinion; the survey questions were created from the intriguing questions. So, this factor may affect the results of the high and positive scores. As a results in the light of the above findings, it can be said that responds of the survey questions are compatible with each other, so teachers and students do.

\section{CONCLUSION}

This study aims two main purposes. The first is related of the variety of the IWB and the view of teachers and students about IWB use in classrooms. Second is related with investigation the use of IWB contribution to teaching of teachers and learning of students in the sixth grade of primary schools.

First, IWB is a contemporary teaching and learning technology tool; its use in the classrooms is rapidly increased in countries around the world. Interactive whiteboards increase the opportunities for a richness and diversity in teaching and learning in the classrooms.

Second, the present study mainly consists of teaching of teachers and learning of students in survey questions, when the IWB is used. Participants emphasized that IWB contributes the improving to teaching and learning significantly in elementary schools. According to the evaluation of teachers and students, the contribution of teaching and learning of the IWB use in classrooms are strongly positive.

The responds of participants are in good agreement with survey questions and reviews of the teachers and students are in overlapped mostly. In the same case, effectiveness of education of the IWB for teaching and learning are found similar results. IWB is used more widely and effectively, if subjects consist of visuals, digits, auditory. Such teaching and learning activities stimulate the teachers' and students' interest, and increase the interaction between the teacher and students. The IWB that make up the theme of our study is related to the contribution of teaching and learning in the view of teachers and students. The responses of teachers and students are strongly positive the use of IWB in classrooms, which supports the contribution of increases students' academic performance. In the study, the responses of teachers and students almost confirm to each other in all areas. 


\section{RECOMMENDATIONS AND FUTURE RESEARCH}

Based on the findings obtained in this study, the following suggestions were developed. Understood from the findings that the participants' views toward IWB use in classrooms and its contribution to teaching and learning are quite positive. By using IWB-teaching technology tools, this type of study can be done with different disciplines, grades and defected persons (auditory, visual, tactile sensation, etc. ). In schools without a laboratory, Using IWB, virtual science experimental studies can be done and its contribution to teaching and learning are possible investigated. The most important is that outputs and findings of the research should share and experiences to help develop professionally.

\section{REFERANCES}

Shenton, A., \& Padgett, L. (2007). From "bored" to screen: the use of the interactive white board for literacy in six primary classrooms in England. Literacy, 41(3):129-136.

Akkoyunlu, B., \& Baskan, G. (2015). School Principals' Opinions on the FATIH Project in Turkey. Procedia Social and Behavioral Sciences, 174, 1497-1502.

Ardichvili, A. (2008). Learning and knowledge sharing in virtual communities of practice: Motivators, barriers, and enablers. Advances in Developing Human Resources, 10 (4): 541-554.

Armstrong, V., Barnes, S., Sutherland, R., Curran, S., Mills, S., \& Thompson, I. (2005). Collaborative research methodology for investigating teaching and learning: The use of interactive whiteboard technology. Educational Review, 57(4): 457-469.

Balta, N., \& Duran, M. (2015). Attitudes of Students and Teachers towards the Use of Interactive Whiteboards in Elementary and Secondary School Classrooms. TOJET: The Turkish Online Journal of Educational Technology, 14 ( 2), 1-23.

Beauchamp, G., \& Parkinson, J. (2005). Beyond the 'wow' factor: developing interactivity with the Interactive whiteboard. School Science Review, 86 (3): 97-103.

Becta. (2006). Teaching Interactively with Electronic Whiteboards in the Primary Phase. Retrieved October 18, 2009 from httppublications. becta. org.ukdisplay. cfmres $\mathrm{ID}=25918$.

Becta. (2008). Harnessing technology: Schools survey, 1-250, http://www.becta.org.uk

Beeland, W.D. (2003). Student Engagement, Visual Learning and Technology: Can Interactive Whiteboards Help? Retrieved April 18, 2003, from the University of New Castle website:

bttp:/ /plato75.ncl.ac.uk/ beeland.pdf

Betcher, C., \& Lee, M. (2009). The interactive whiteboard revolution-Teaching with IWBs. Victoria, Australia: ACER Press. schoolnet.org.za/CoL/../iwb_revolution

Cakiroglu, O. (2015). Teachers' views on the use of Interactive Whiteboards in Secondary Schools. Eurasia Journal of Mathematics, Science \& Technology Education, 11(2), 251-259.

Celik, S. (2012). Competency Levels of Teachers in Using Interactive Whiteboards. Contemporary Educational Technology, 3 (2): 115-129

Cintia, L., Gheorghiu, I., \& Colibaba C.A. (2014). Stimulating Students 'Motivation to Learn Science.

Practical Application of Science, 2 (3), 251-256

Cogill, J. (2002). How is interactive whiteboard being used in the primary school and how does it affect teachers and teaching. Retrieved November 6, 2009, from

www.virtuallearning.org.uk/whiteboards/IFS_Interactive_whiteboards_in_the_primary_school. 
Digregorio, P., \& Sobel-Lojeski, K. (2010). The Effect of IWBs on Students Performance and Learning: A Literature Review. Journal of Educational Technology Systems, 38 (3): 255-312.

Dogan, D., Cinar, M., \& Seferoglu, S. S. (2016). “One Laptop per Child” projects and FATIH project:

A comparative examination. SDU International Journal of Educational Studies, 3(1), 1-26).

Emron, S., \& Dhindsa, H. S. (2010). Integration of Interactive Whiteboard Technology to Improve Secondary Science Teaching and Learning. International Journal for Research in Education, 28.

European Commission; Survey of Schools: ICT in Education, Final Study Report. (2013).

$<$ www.europeanschoolnet.org-www.eun.org>

Georgieva, K., Stoykova, V., Ivanova, N., \& Dimova, E. (2015). Application of Information Technologies and Interactions Tools for Improving Educational Quality. CBU International Conference Proceedings, 3, 468-474.

Ghavifekr, S., \& Rosdy, W.A.W. (2015). Teaching and learning with technology: Effectiveness of ICT integration in schools. International Journal of Research in Education and Science (IJRES), 1(2), 175-191.

Glover, D., Miller, D., Averis, D., \& Door, V. (2005). The interactive whiteboard: A literature

Technology, Pedagogy and Education, 14(2), 155-170.

Hall, R. (2011). Interactive White Boards: Changing Students' Attitudes about Science. Leadership Research, 28(1).

Hartsell, T., Herron, S. S., Fang, H., \& Rathod, A. (2010). Improving teachers' self-Confidence in Learning Technology Communication. Technology Education, 6(2), 47-6.

Hennessy, S., \& Warwick, P. (2010). (Eds) Research into School Teaching and Learning with Whole Class Interactive Technologies. Technology, Pedagogy and Education (Special Edition), 19 (2), 127-131.

Jankowska, M., \& Atlay, M. (2008). Use of creative space in enhancing students' engagement.Innovations in Education and Teaching International, 45(3), 271-279.

Khan, S., Meyers, E., Gowen, E., \& Bergman, K. (2014). Online information seeking and knowledge sharing practices of science teachers. Proceedings of the Association for Information Science and Technology, 51 (1), 1-4 . DOI: 10.1002/meet.2014.14505101125

Karsenti, T. (2016). The Interactive Whiteboard (IWB): Uses, Benefits, and Challenges. Library and Archives Canada, ISBN: 978-2-923808-52-9 February 2016. iwb.crifpe.ca/files/Rapport.pdf

DOI: $10.13140 /$ RG.2.1.3048.6169

Kayak, S. \& Kir, E. (2015). Evaluation of candidate language teachers' level of knowledge and ideas towards the use of interactive whiteboard. Journal of Computer and Education Research, 3(5), 33-60.

Kilic, E., Guler, C., Celik, H. E.,\& Tatli, C. (2015). Learning with interactive whiteboards: Determining the factors on promoting 1wbs to students by Technology Acceptance Model. Interactive Technology and Smart Education, 12, 4, 285-297. Doi.org/10.1108/TTSE-05-2015-0011

Kristin, Y., \& Lynn, C. (2011). Interactive Whiteboards: A Tool for Enhancing Teaching and Learning. National Teacher Education Journal, 4 (2), 81-86.

Kurt, A. A., Kuzu, A., Dursun, O.O., Gulpinar, F., \& Gultekin, M. (2013). Pilot Evaluation of Implementation Process of the Fatih Project: Teachers' Views. Journal of Instructional Technologies \& Teacher Education, 2(1),1-23.

Liang, T.H., Huang, Y.M., \& Tsai, C.C. (2012). An Investigation of Teaching and Learning Interaction Factors for the Use of the Interactive Whiteboard Technology. Educational Technology \& Society, 15 (4), 356-367 
Littleton, K. (2010). Research into teaching with whole-class interactive echnologies: Emergent themes. Technology, Pedagogy and Education, 19 (2),285-292.

López, O. S. (2010). The Digital Learning Classroom: Improving English Language Learners' Academic success in mathematics and reading using interactive whiteboard technology. Computers \& Education, 54(4), 901-915.

Manny-Ikan, E., Dagan, O., Mada, K. (2011). Using the Interactive White Board in Teaching and Learning An Evaluation of the Smart Classroom. Interdisciplinary Journal of E-Learning and Learning Objects, 7, 249-271.

Mathews-Aydinli, M. J., \& Elaziz, F. (2010). 'Turkish students' and teachers' attitudes toward the use of IWBs in EFL classrooms. Computer Assisted Language Learning, 23(3), 235252

Mavers, D. (2009). Teaching and learning with a visualizer in the primary classroom: modelling graph making. Learning, Media and Technology, 34 (1), 11-26

Mercer, N., Warwick, P., Keshner, R., \& Staarman, J.K. (2010). Can the interactive whiteboard help to provide 'dialogic space' for children's collaborative activity? Language and Education, 24 (5), 367-384. http://dx.doi.org/10.1080/09500781003642460

Morgan, G. L. (2008). Improving Student Engagement: Use of the Interactive Whiteboard as an Instructional Tool to Improve Engagement and Behavior in the Junior High School Classroom. Doctoral Dissertations and Projects. Paper 121. http://digitalcommons.liberty.edu/doctoral/121

Pour, M. G. (2013). The Role of Interactive Whiteboards (IWB) in Education. Acme International Journal of Multidisciplinary Research, 1(4):1-6

Private Communication

Rule, A.C., Stefanich, G.P., Boody, R.M., \& Peiffer, B. (2011). Impact of Adaptive Materials on Teachers and their Students with Visual Impairments in Secondary Science and Mathematics Classes. International Journal of Science Education, 33 (6), 865-887. http://dx.doi.org/10.1080/09500693.2010.506619

Streiner, D. L. (2003). Starting at the beginning: an introduction to coefficient alpha and internal consistency. Journal of Personality Assessment, 80, 99-103

Swan, K., \& van 't Hooft, M. (2012). IWBs and student achievement: A question of Use. Ricerc Azion, $4(2), 257-266$.

Tertemiz, N., Sahin, D., Can, B., \& Duzgun, S. (2015). Views of Primary School Teachers and Students about The Interactive Whiteboard. Procedia-Social and Behavioural Sciences, 186, 1289-1295. doi:10.1016/j.sbspro.2015.04.099

Tirotta, T., Torff, B., \&Tirotta, R. (2010). Interactive whiteboards produce small gains in elementary students' self-reported motivation in mathematics. Computers \& Education, 54, 379-383.

Tomei, L.A. (2013). Top 10 Technologies for Designing 21st Century Instruction. International Journal of Information and Communication Technology Education (IJICTE), 9(3), 80-93.

DOI: $10.4018 /$ jicte.2013070106

Tunaboylu, C., \& Demir, E. (2016). The Effect of Teaching Supported by IWB on Students' Mathematical Achievements in Lower Secondary Education. Journal of Education and Learning, 6 (1), 81-94. doi:10.5539/jel. v6n1p81

Turel, Y. K., \& Johnson, T. E. (2012). Teachers' Belief and Use of Interactive Whiteboards for Teaching and Learning. Educational Technology \& Society, 15 (1), 381-394. 
Xu, H. L., \& Moloney, R. (2011). "It Makes the Whole Learning Experience Better": Student Feedback on the Use of the Interactive Whiteboard in Learning Chinese at Tertiary Level. Asian Social Science, 7(11), 119-133. doi:10.5539/ass.v7n11p20

Wood, R., \& Ashfield, J. (2008). The use of the IWB for creative teaching and learning in literacy and mathematics: A case study. British Journal of Educational Technology, 39(1), 84-96.

Yang, J.Y., \& Teng, Y.W. (2014). Perceptions of Elementary School Teachers and Students Using IWBs in English Teaching and Learning. Journal of Interactive Learning Research, 25 (1), 1-29.

\section{Citation Information}

Çakıroglu, O. (2016). Teachers and Students Views on the use of IWBs in Secondary Schoolsfor Enhancing Classroom Teaching and Learning. Dicle Üniversitesi Ziya Gökalp Eğitim Fakültesi Dergisi, 29, 395407. 